Policy Contribution Issue $n^{\circ} 7 \mid 2017$

\title{
What happened to global banking after the crisis?
}

\author{
Dirk Schoenmaker
}

\section{Executive summary}

DIRK SCHOENMAKER (dirk schoenmaker@bruegel.org) is a Senior Fellow at Bruegel

The author would like to thank Bennet Berger and Ines Goncalves Raposo for research assistance, and Maria Demertzis, Patty Duijm and Guntram Wolff for comments.

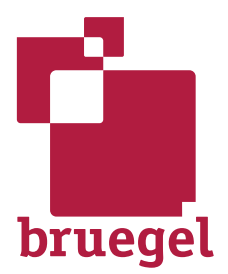

THE GLOBAL FINANCIAL crisis allegedly led to the end of global banking. However, we find that reports of the demise of global banking are premature. Among the global systemically important banks, we find that there has been a shift of business from the global European banks to the more domestic Asian banks, which are gradually increasing their global reach. The US banks have maintained their strong position. Within Europe, we find a mixed picture. The euro-area banks have maintained their global reach, while UK and Swiss banks have experienced a significant decline in their geographic reach.

OVERALL, WE CONCLUDE that the decline in cross-border banking is largely a result of a composition effect (ie a reshuffling within the global banking champions' league); it is far less a consequence of a reduced global reach of individual banks.

ON THE REFORM agenda, an important policy measure has been the increase of capital at the large global banks. Overall, we find an almost doubling of the leverage ratio (Tier 1 capital divided by total assets) from 3.1 percent in 2007 to 5.9 percent in 2015 . This is very welcome. However, the euro area, Japan, Sweden and Switzerland trail behind with leverage ratios between 4 and 5 percent. We recommend these countries should bring the leverage ratios of their largest banks more into line with international practice.

THE EURO-AREA BANKS are in the twilight zone. These banks have reduced in size (about 20 percent), which was to be expected because of overbanking in Europe, but have maintained their geographic reach. Nevertheless, the capitalisation of euro-area banks lags that of their Chinese and US peers. While the European Central Bank has made progress on the size and consistency of Pillar 2 capital requirements, we strongly recommend strengthening the capitalisation of the euro-area banks further. Increasing capital can be done through a combination of retained earnings and rights issues.

A FINAL POINT for the euro-area banks is the fiscal backstop, which is important for financial stability and for geopolitical reasons. The ECB is already responsible for the prudential supervision of the large banks in the euro area. Financial stability requires further strengthening of the euro area's unfinished banking union to generate the desired incentives for banks and national authorities. Further risk sharing (through the European Stability Mechanism) should go hand-in-hand with additional harmonisation and the limitation of banks' holdings of individual countries' sovereign bonds. A completed banking union would bring the euro-area banks to par with their Chinese and US counterparts, which have a central system of supervision and crisis management behind them. 


\section{Introduction}

Reading reports on the end of global banking reminds one of Mark Twain, who famously wrote more than a century ago: "The report of my death was an exaggeration" (as reported by Marshall White, 1897). The purpose of this paper is to review what has happened to the global banks, which still seem to be alive.

The large global banks were at the heart of the global financial crisis. In response to the crisis, the international Financial Stability Forum was upgraded to the Financial Stability Board (FSB) in 2009, with the full participation of finance ministers and even heads of government. The newly established FSB then published an integrated set of policy measures, such as capital surcharges and resolution plans, to address the systemic and moral hazard risks associated with global systemically important banks (G-SIBs).

Eight years later, it is time to take stock of the impact of these measures. We answer three questions on what happened to the G-SIBs. First, have they shrunk in size? Second, are they better capitalised? Third, and in reference to the reported end of global banking, have they reduced their global reach? A review of the resolution plans of the G-SIBs is beyond the scope of this paper. Some jurisdictions have only recently started to implement these plans. Moreover, the resolution plans, with the notable exception of those of the US authorities, are made behind a wall of secrecy, which hinders academic scrutiny.

On the important issue of capitalisation, we find that the strengthening of the Basel capital framework combined with capital surcharges for the G-SIBs has led to a substantial rise in capital levels. The leverage ratio, defined as Tier 1 capital divided by total assets, increased from 3.1 percent to 5.9 percent on average for the G-SIBs between 2007 and 2015. However, we find an uneven distribution of the higher leverage ratios. The euro area, Japan, Sweden and Switzerland trail behind with ratios between 4 and 5 percent each in 2015.

Using BIS International Banking Statistics, Claessens (2017) reported that cross-border banking has fallen by some 20 percent from its all-time high in early 2008 because of the global financial crisis and the subsequent euro-area crisis. But Claessens (2017) also noted that global banking was rising fast ahead of the global financial crisis; we are now back at the end-2006 level of cross-border banking. Using bottom-up data from the G-SIBs, which form about half of the total banking system, we find that the foreign share of these G-SIBs' total assets dropped from 44 percent in 2007 to 35 percent in 2015, also a 20 percent decline. Further analysis reveals a strong composition effect: a shift of business from the global European banks to the more domestic Asian banks. The US banks retain their strong position. So, the decline in cross-border banking is more a result of a reshuffle of the global banking champions' league, than of the reduced global reach of individual banks.

Claessens and Van Horen (2014) indicated that the rise in foreign bank entry was spurred by reforms in various countries, including the opening up of eastern Europe and the liberalisation of entry by Latin American and East Asian countries. Moreover, it also reflected the sharp increase in general financial globalisation before the global financial crisis. Schoenmaker and Wagner (2013) reported an overexposure of western European banks to the United States prior to the global financial crisis.

On the post-crisis decline, government intervention plays a role. Rose and Wieladek (2014) showed that foreign banks reduced their fraction of UK loans, while nationalised domestic banks kept their loan mix in the United Kingdom. Kleymenova et al (2016) reported that US banks on entry into the Troubled Asset Relief Programme (TARP) reduced their foreign lending but not their domestic lending. By contrast, De Haas et al (2015) showed that in general both domestic and foreign banks sharply curtailed credit in eastern Europe during the crisis, but that foreign banks that participated in the Vienna Initiative were relatively stable lenders.

Following the global financial crisis and in the wake of regulatory reform, McCauley, McGuire and Von Peter (2012) expected that the trend toward decentralised multinational banking would likely accelerate, particularly if liquidity requirements were to be applied 
by host regulators on a legal entity basis. This is part of a broader trend of moving resources within banking groups becoming more restricted after the crisis (see Cerutti and Claessens, 2007, and Schoenmaker, 2016, on ringfencing). Claessens (2017) argued that banking has become more regional. However, we find that both the regional and global shares of international banking have declined evenly.

While many general factors, such as government intervention, regulatory reform and reduced host-country attractiveness, have been investigated, we present new evidence on home-country related factors. In particular, we argue that the credibility (or lack of it) of the fiscal backstop for large banks can partly explain the reduction in foreign presence (Schoenmaker, 2016). We present data that the UK and Swiss banks have declined both in size and foreign reach. Banks from the European banking union are in the twilight zone: they have reduced in size, albeit to a lesser degree than the UK and Swiss banks, but have kept their geographic spread. The reduction in size was predicted because Europe is overbanked and needs to make a transition towards a healthier mix of bank and market financing (Langfield and Pagano, 2016).

\section{Data on global banks}

To get a rich picture of global banking, we take a bottom-up approach to the collection of data on the foreign reach of G-SIBs. The methodology to assess the global systemic importance of banks is based on five indicators: size, global activity, interconnectedness, substitutability of services and complexity (see Schoenmaker, 2013, for a review). Because of their global activity, this group of G-SIBs is the most relevant for research on global banking.

The FSB's original list of G-SIBs of 2011 is updated annually. To avoid survivor bias, we include in our sample all G-SIBs, 30 from the 2016 list and three (BBVA, Commerzbank and Lloyds Bank) from earlier years (FSB, 2016). Table 1 shows that the G-SIBs account for about half of the total banking assets in the major banking countries, with the euro area treated as a single country area because of the introduction of the European banking union with centralised supervision of the large banks.

Table 1: Share of G-SIBs in total banking assets [in \$ billion; 2015]

\begin{tabular}{lccc}
\hline Country & Total banking assets & Assets of G-SIBs & G-SIBs' share \\
\hline China & 30,730 & 11,577 & $38 \%$ \\
\hline Euro area & 30,208 & 13,192 & $44 \%$ \\
\hline Japan & 9,415 & 6,086 & $65 \%$ \\
\hline United Kingdom & 10,179 & 7,092 & $70 \%$ \\
\hline United States & 15,564 & 10,303 & $66 \%$ \\
\hline Total & 96,095 & 48,249 & $50 \%$ \\
\hline
\end{tabular}

Source: Total assets from Schoenmaker and Véron [2016]; G-SIBs from Table 2. Notes: This table contains the major banking economies. The first column is total banking assets in a country. The second column contains the total bank assets of the G-SIBs in a country. These five countries contain 30 of the $33 \mathrm{G}$-SIBs in our sample.

To assess the extent of the retreat in global banking, we compare the current make-up of the G-SIBs with that at the end of 2007, just before the global financial crisis arrived. We look at three aspects: size, capital and geographical spread. Size is straightforwardly measured by total assets. For capital, we examine the leverage ratio, which is a simple and undistorted measure of capitalisation. A bank's leverage ratio is defined as a bank's Tier 1 capital divided by its total assets. While Basel has harmonised the definition of Tier 1 capital, the US Gener- 
ally Accepted Accounting Principles allow netting, which reduces the total assets of US banks. Our data source, SNL, restates the total assets of US banks and of Credit Suisse (based on US GAAP) to IFRS estimates. We use these IFRS estimates in order to make the leverage ratios comparable (Table 2). For the geographic spread, we take from the respective annual reports of the G-SIBs the segmentation of assets over the home country, the rest of the region and the rest of the world (see Duijm and Schoenmaker, 2017, for a full explanation of the methodology). The leverage ratio and geographical segmentation for a group of banks are calculated as a weighted average, with total assets as weights.

To compare the changes over the 2007-15 period, we calculate the percentage change in total assets and the change in percentage points of the leverage ratio and geographic shares. The percentage points for the geographic shares add up to zero. Table 3 presents our data.

Table 2: Computed leverage ratio based on IFRS assets [2015]

\begin{tabular}{|c|c|c|c|c|c|c|}
\hline & Banking groups & $\begin{array}{c}\text { Tier } 1 \\
\text { Capital }\end{array}$ & $\begin{array}{c}\text { Original } \\
\text { assets }\end{array}$ & $\begin{array}{l}\text { Self- } \\
\text { reported } \\
\text { leverage } \\
\text { ratio }\end{array}$ & $\begin{array}{l}\text { IFRS } \\
\text { assets }\end{array}$ & $\begin{array}{l}\text { Computed } \\
\text { leverage } \\
\text { ratio }\end{array}$ \\
\hline 1 & BBVA & 53 & 815 & $6.0 \%$ & 815 & $6.5 \%$ \\
\hline 2 & BNP Paribas & 83 & 2,166 & $4.0 \%$ & 2,166 & $3.9 \%$ \\
\hline 3 & Commerzbank & 30 & 579 & $4.5 \%$ & 579 & $5.1 \%$ \\
\hline 4 & Deutsche Bank & 63 & 1,769 & $3.5 \%$ & 1,769 & $3.6 \%$ \\
\hline 5 & Groupe BPCE & 57 & 1,267 & $4.9 \%$ & 1,267 & $4.5 \%$ \\
\hline 6 & $\begin{array}{l}\text { Groupe Crédit } \\
\text { Agricole }\end{array}$ & 85 & 1,845 & $5.7 \%$ & 1,845 & $4.6 \%$ \\
\hline 7 & ING Bank & 44 & 911 & $4.1 \%$ & 911 & $4.8 \%$ \\
\hline 8 & Santander & 80 & 1,456 & $4.7 \%$ & 1,456 & $5.5 \%$ \\
\hline 9 & Société Générale & 54 & 1,449 & $3.8 \%$ & 1,449 & $3.7 \%$ \\
\hline \multirow[t]{2}{*}{10} & UniCredit Group & 49 & 935 & $4.4 \%$ & 935 & $5.2 \%$ \\
\hline & Total euro area & 598 & 13,192 & $4.5 \%$ & 13,192 & $4.5 \%$ \\
\hline 1 & Bank of America & 181 & 2,144 & $6.4 \%$ & 2,784 & $6.5 \%$ \\
\hline 2 & $\begin{array}{l}\text { Bank of New York } \\
\text { Mellon }\end{array}$ & 21 & 394 & $4.9 \%$ & 405 & $5.2 \%$ \\
\hline 3 & Citigroup & 176 & 1,731 & $7.1 \%$ & 2,299 & $7.7 \%$ \\
\hline 4 & Goldman Sachs & 82 & 861 & $5.9 \%$ & 1,582 & $5.2 \%$ \\
\hline 5 & JP Morgan Chase & 200 & 2,352 & $6.5 \%$ & 3,254 & $6.2 \%$ \\
\hline 6 & Morgan Stanley & 67 & 787 & $5.8 \%$ & 1,230 & $5.4 \%$ \\
\hline 7 & State Street & 15 & 245 & $5.8 \%$ & 252 & $6.0 \%$ \\
\hline \multirow[t]{2}{*}{8} & Wells Fargo & 165 & 1,788 & $7.7 \%$ & 1,855 & $8.9 \%$ \\
\hline & Total United States & 907 & 10,303 & $6.6 \%$ & 13,661 & $6.6 \%$ \\
\hline 1 & $\begin{array}{l}\text { Agricultural Bank } \\
\text { of China }\end{array}$ & 186 & 2,740 & $6.3 \%$ & 2,740 & $6.8 \%$ \\
\hline 2 & Bank of China & 198 & 2,590 & $7.0 \%$ & 2,590 & $7.6 \%$ \\
\hline 3 & $\begin{array}{l}\text { China Construction } \\
\text { Bank }\end{array}$ & 220 & 2,826 & $7.3 \%$ & 2,826 & $7.8 \%$ \\
\hline 4 & $\begin{array}{l}\text { Industrial and } \\
\text { Commercial Bank } \\
\text { of China }\end{array}$ & 274 & 3,421 & $7.5 \%$ & 3,421 & $8.0 \%$ \\
\hline & Total China & 878 & 11,577 & $7.1 \%$ & 11,577 & $7.6 \%$ \\
\hline
\end{tabular}




\begin{tabular}{|c|c|c|c|c|c|c|}
\hline \multicolumn{7}{|c|}{ Table 2 continued } \\
\hline 1 & Barclays & 78 & 1,651 & $4.5 \%$ & 1,651 & $4.7 \%$ \\
\hline 2 & HSBC & 153 & 2,410 & $5.0 \%$ & 2,410 & $6.4 \%$ \\
\hline 3 & $\begin{array}{l}\text { Lloyds Banking } \\
\text { Group }\end{array}$ & 54 & 1,189 & $4.8 \%$ & 1,189 & $4.5 \%$ \\
\hline 4 & $\begin{array}{l}\text { Royal Bank of } \\
\text { Scotland }\end{array}$ & 68 & 1,202 & $5.6 \%$ & 1,202 & $5.7 \%$ \\
\hline \multirow[t]{2}{*}{5} & Standard Chartered & 43 & 640 & $5.5 \%$ & 640 & $6.7 \%$ \\
\hline & Total UK & 396 & 7,092 & $5.0 \%$ & 7,092 & $5.6 \%$ \\
\hline 1 & Mitsubishi UFJ FG & 132 & 2,602 & $4.8 \%$ & 2,621 & $5.0 \%$ \\
\hline 2 & Mizuho FG & 77 & 1,883 & $4.0 \%$ & 1,883 & $4.1 \%$ \\
\hline \multirow[t]{2}{*}{3} & Sumitomo Mitsui FG & 80 & 1,600 & $4.6 \%$ & 1,616 & $5.0 \%$ \\
\hline & Total Japan & 289 & 6,086 & $4.5 \%$ & 6,120 & $4.7 \%$ \\
\hline 1 & Credit Suisse & 53 & 827 & $4.5 \%$ & 1,098 & $4.9 \%$ \\
\hline \multirow[t]{2}{*}{2} & UBS & 45 & 942 & $4.0 \%$ & 942 & $4.7 \%$ \\
\hline & Total Switzerland & 98 & 1,769 & $4.2 \%$ & 2,040 & $4.8 \%$ \\
\hline \multirow[t]{2}{*}{1} & Nordea & 29 & 703 & $4.6 \%$ & 703 & $4.1 \%$ \\
\hline & Total Sweden & 29 & 703 & $4.6 \%$ & 703 & $4.1 \%$ \\
\hline 33 & Total & 3,194 & 50,720 & $5.6 \%$ & 54,383 & $5.9 \%$ \\
\hline
\end{tabular}

Source: Bruegel (see Table 3). Notes: The first column contains the number of G-SIBs - 30 from 2016 and 3 from earlier years. Tier 1 capital and assets are in US\$ billions. The second column provides Tier 1 capital. The third column reports the original assets (US GAAP or IFRS). The fourth column gives the self-reported leverage ratio of banks. To make the leverage ratio comparable across regions, they are calculated on an IFRS assets basis (no netting). The computed leverage ratio in column 6 is calculated on the basis of the IFRS assets: Tier 1 Capital / total IFRS assets.

Table 3: Changes in size, capital and geographical spread of G-SIBs [2007-2015]

\begin{tabular}{|c|c|c|c|c|c|c|}
\hline & & & & - $2007-$ & & \\
\hline No. G-SIBs & Region & Total assets & Capital & Home & Region & World \\
\hline 10 & Euro area & 16,213 & $2.70 \%$ & $48 \%$ & $28 \%$ & $24 \%$ \\
\hline 8 & United States & 9,329 & $3.90 \%$ & $71 \%$ & $6 \%$ & $23 \%$ \\
\hline 4 & China & 3,639 & $6.00 \%$ & $92 \%$ & $4 \%$ & $3 \%$ \\
\hline 5 & $\begin{array}{l}\text { United } \\
\text { Kingdom }\end{array}$ & 10,823 & $2.70 \%$ & $49 \%$ & $17 \%$ & $34 \%$ \\
\hline 3 & Japan & 4,344 & $3.70 \%$ & $72 \%$ & $5 \%$ & $23 \%$ \\
\hline 2 & Switzerland & 3,211 & $1.70 \%$ & $23 \%$ & $29 \%$ & $48 \%$ \\
\hline 1 & Sweden & 569 & $3.70 \%$ & $35 \%$ & $65 \%$ & $0 \%$ \\
\hline \multirow[t]{3}{*}{33} & Total & 48,128 & $3.10 \%$ & $56 \%$ & $18 \%$ & $26 \%$ \\
\hline & & & & - 2015 - & & \\
\hline & Region & Total assets & Capital & Home & Region & World \\
\hline 10 & Euro area & 13,192 & $4.50 \%$ & $49 \%$ & $30 \%$ & $22 \%$ \\
\hline 8 & United States & 10,303 & $6.60 \%$ & $75 \%$ & $3 \%$ & $22 \%$ \\
\hline 4 & China & 11,577 & $7.60 \%$ & $90 \%$ & $6 \%$ & $4 \%$ \\
\hline 5 & $\begin{array}{c}\text { United } \\
\text { Kingdom }\end{array}$ & 7,092 & $5.60 \%$ & $53 \%$ & $9 \%$ & $38 \%$ \\
\hline 3 & Japan & 6,086 & $4.70 \%$ & $65 \%$ & $9 \%$ & $27 \%$ \\
\hline 2 & Switzerland & 1,769 & $4.80 \%$ & $30 \%$ & $22 \%$ & $48 \%$ \\
\hline 1 & Sweden & 703 & $4.10 \%$ & $28 \%$ & $69 \%$ & $3 \%$ \\
\hline 33 & Total & 50,720 & $5.90 \%$ & $65 \%$ & $14 \%$ & $21 \%$ \\
\hline
\end{tabular}




\begin{tabular}{|c|c|c|c|c|c|c|}
\hline \multicolumn{7}{|c|}{ Table 3 continued } \\
\hline & \multirow[b]{2}{*}{ Region } & \multicolumn{5}{|c|}{ Change 2007-15 } \\
\hline & & Total assets & Capital & Home & Region & World \\
\hline 10 & Euro area & $-19 \%$ & $1.80 \%$ & $1 \%$ & $1 \%$ & $-2 \%$ \\
\hline 8 & United States & $10 \%$ & $2.70 \%$ & $5 \%$ & $-3 \%$ & $-2 \%$ \\
\hline 4 & China & $218 \%$ & $1.60 \%$ & $-3 \%$ & $2 \%$ & $1 \%$ \\
\hline 5 & $\begin{array}{c}\text { United } \\
\text { Kingdom }\end{array}$ & $-34 \%$ & $2.90 \%$ & $4 \%$ & $-8 \%$ & $4 \%$ \\
\hline 3 & Japan & $40 \%$ & $1.00 \%$ & $-8 \%$ & $4 \%$ & $4 \%$ \\
\hline 2 & Switzerland & $-45 \%$ & $3.10 \%$ & $7 \%$ & $-7 \%$ & $0 \%$ \\
\hline 1 & Sweden & $23 \%$ & $0.40 \%$ & $-7 \%$ & $4 \%$ & $3 \%$ \\
\hline 33 & Total & $5 \%$ & $2.70 \%$ & $9 \%$ & $-4 \%$ & $-5 \%$ \\
\hline
\end{tabular}

Source: Assets and capital from SNL, 10-K Reports, Annual Reports; Geographic spread for European banks from Duijm and Schoenmaker (2017) and for US and Asian banks updated from Schoenmaker (2013). Notes: The first column contains the number of G-SIBs - 30 from 2016 and 3 from earlier years. Total assets are in US\$ billions and sum the total assets of the G-SIBs in the respective region or country. Capital is measured as the leverage ratio (Tier 1 equity / total assets). To make the leverage ratio comparable across regions, they are calculated on an IFRS basis (no netting); see Table 2 for individual banks. The geographical segmentation of assets covers the home country, the rest of the region or continent (Americas, Europe and Asia) and the rest of the world. The leverage ratio and geographical spread are calculated as a weighted average of the G-SIBS in the respective region or country. The change in total assets is calculated as a percentage; the change in capital (leverage ratio) is in percentage points; changes in the geographical weights (of home, region and world] are in percentage points and thus add up to zero.

The overall trend indicates no retreat of global banks themselves, with a small pick-up of 5 percent in total assets between 2007 and 2015. Although this percentage is much lower than the compounded economic growth of world GDP at 28 percent over these years (Schoenmaker, 2016), there is no decline in global banks. Next, we find a substantial increase in capitalisation from 3.1 to 5.9 percent. Policymakers have thus been successful in increasing the capital level in the banking sector.

Looking at the geographical spread, we note a retreat in global banking (defined as foreign assets in the rest of the region and in the rest of the world) from 44 percent in 2007 to 35 percent in 2015. This 20 percent decline is in line with other reports on global banking (eg Claessens, 2017). It should be noted that the decline is evenly shared between the regional share (from 18 to 14 percent) and the global share (from 26 to 21 percent). Unlike other studies (Claessens, 2017; Claessens and Van Horen, 2014), we do not observe an increase in regional banking at the expense of global banking. The next section discusses the country-specific details.

\section{Country patterns in global banking}

While most research on global banking is done from a host-country perspective (eg De Haas et al, 2015; Rose and Wieladek, 2014), we take a home-country perspective. Can we explain differences in global reach by the home country of these global banks? The G-SIBs are located in the world's major economies. Only six countries - China, the euro area, Japan, Switzerland, the United Kingdom and the United States - are home to two or more large G-SIBs, and Sweden has one G-SIB. We look at three aspects: size, capital and cross-border banking.

\subsection{Size of banks}

On size, a clear country pattern emerges. The Asian countries, China and Japan, were not directly hit by the global financial crisis and their banks kept on growing between 2007 and 2015 , with an increase in total assets of 218 and 40 percent respectively (see the bottom panel of Table 3). After the swift recapitalisation of the US banks in March 2009, the US banks, and 
After recapitalisation, the US banks, and US economy, resumed growth. By contrast, the picture in Europe is one of decline the US economy, resumed growth. By contrast, the picture in Europe is one of decline, with a strong drop in the UK (-34 percent) and Switzerland (-45 percent). The decline in euro-area banking is intermediate at -19 percent.

The decline in Europe can be explained by three factors. The first is structural: Europe is overbanked, with 80 percent of credit provided by banks and only 20 percent by markets (Langfield and Pagano, 2016). Europe is thus in a transition from bank-based to more market-based financing. This is a good development, as a healthy mix of bank and market financing diversifies the funding sources of corporates.

The second factor is crisis related. European banks were particularly hard hit by the global financial crisis that originated in the US, because of their overexposure to the US (Schoenmaker and Wagner, 2013). Next, the euro sovereign crisis hit the European economies and banks again. Related to this 'double hit' were the slow and unconvincing attempts to recapitalise European banks. While the US Treasury published the capital shortfall (if any) of US banks in dollar amounts, which the respective banks had to cover with fresh capital after the March 2009 stress test, the European Banking Authority defined a target capital ratio (capital divided by risk weighted assets), despite several warnings from academics (eg Acharya et al, 2011). European banks with a shortfall were allowed to meet the target capital ratio either by fresh capital and/or downsizing assets. This triggered a process of deleveraging.

The third factor is policy related. The UK and Switzerland have enacted major reforms (structural reforms and higher capital charges) with the official aim of increasing the resilience of their banking systems, and the intended side effect of downsizing their large banks and reducing their foreign activities at the same time (Schoenmaker, 2016). The new requirements have been disproportionally stringent on the largest banks compared to the rest of the banking system. The Vickers separation of retail and wholesale banking, which affects the large UK banks, is a case in point. The main purpose of this separation is to limit the contingent liability of the UK taxpayer for providing support to the British banking system (Goodhart, 2012). Moreover, the UK and Switzerland have imposed higher capital surcharges than other countries on their large banks. In contrast, the major euro-area countries have implemented some lighter 'Liikanen' reforms (Liikanen, 2012).

\subsection{Bank capital}

On capital, we report an almost doubling of the average leverage ratio from 3.1 to 5.9 percent. Looking at the change between 2007 and 2015, Switzerland, the UK and the US have implemented the highest increases of 3.1, 2.9 and 2.7 percentage points respectively (the bottom panel of Table 3 reports the changes). On current capital levels, China and the US are leading with leverage ratios for their G-SIBs of 7.6 and 6.6 percent respectively, followed by the UK with 5.6 percent. The other European countries and Japan are trailing behind with ratios of between 4 and 5 percent. The banks from the latter countries are operating close to the bare minimum of 3.5 percent, which is the sum of the Basel leverage ratio of 3 percent and the average G-SIB surcharge of 0.5 percent of total assets ${ }^{1}$. Figure 1 on the next page shows the current capital levels of the G-SIBs in the various countries.

To analyse the increase in capital in more detail, we split the 2.7 percentage points increase into an increase arising from changes in capital at individual banks and an increase from changes in the size (measured by assets) of individual banks. The latter is the composition effect measuring the relative weight of individual G-SIBs in the overall G-SIB population. Table 4 reports that 78 percent of the 2.7 percentage points increase is due to changes in capital at individual G-SIBs, which confirms the overall increase in capital because of Basel 3. Only 22 percent of the increase comes from changes in the size of individual G-SIBs, which

1 The average G-SIB surcharge is 1.33 percent of risk-weighted assets. This is calculated as the weighted average of surcharges ranging from 1 to 2.5 percent; weighted by the number of banks in each bucket (FSB, 2016). Berger et al (2016) find that the risk-weighted assets are about 34 percent of total assets for G-SIBs. The leverage ratio equivalent (based on total assets) is then 0.45 percent $\left(=34\right.$ percent $^{*} 1.33$ percent). 
measures their relative contribution to the group of G-SIBs.

Figure 1: Capital of G-SIBs, selected countries [as \% of total assets; 2015]

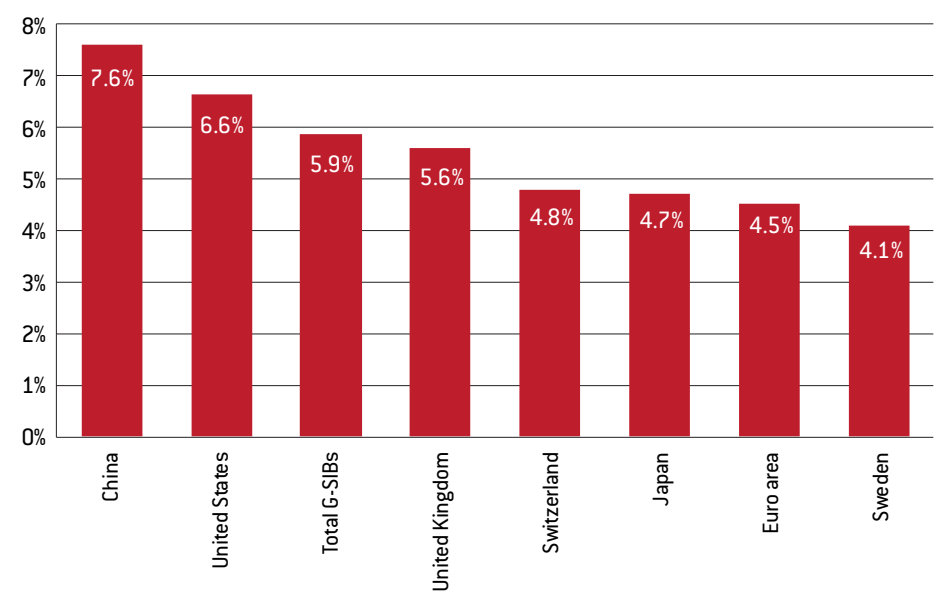

Source: Bruegel (see Table 2). Notes: Capital is measured as the leverage ratio (Tier 1 equity/total assets). To make the leverage ratio comparable across regions, they are calculated on an IFRS basis (no netting).

Table 4: Change in capital of G-SIBs [2007-2015]

\begin{tabular}{lcc}
\hline & Changes (in percentage points) & Share in overall change (in \%) \\
\hline Changes in capital & $2.3 \%$ & $78 \%$ \\
\hline Changes in bank size & $0.6 \%$ & $22 \%$ \\
\hline Combined effect & $-0.2 \%$ & \\
\hline Overall change 2007-15 & $2.7 \%$ & \\
\hline
\end{tabular}

Source: Bruegel (see Table 3). Notes: The overall change in capital from 2007 to 2015 (bottom row) is split into a part arising from changes in the capital of individual G-SIBs and a part arising from changes in the size of individual G-SIBs, which measures their relative share in the total group of G-SIBs (the composition effect). The third row is the combined effect of capital and weight changes.

While good progress has been made on average with higher capital charges, Europe and Japan are behind in the pack. We recommend that they converge towards the international practice of well-capitalised banks with leverage ratios of 5.5 to 6 percent. However, the negotiation stance of the European Commission, and of some major European regulators, is that the new Basel IV package should not lead to extra capital requirements in total for the European banking sector, for fear it would result in reduced lending (Financial Times, 2016). The banks convinced the European Commission that higher capital charges would lead to a reduction in lending. But is that true? Looking at the impact of higher Basel II capital requirements for trade finance in 2012, Demir et al, (2016) found that the effect on international trade of a shock to the supply of trade finance is more subtle than suggested in the popular press, inferred from banking surveys or typically assumed in the trade finance literature. While risk-weight changes brought about by Basel II affect trade shares, the overall trade growth was unaffected.

More generally, US evidence also suggests that higher capital requirements do not necessarily lead to less lending. The US banks resumed business after a swift and decisive recapitalisation in March 2009, supporting economic growth in the US. By contrast, Gambacorta and Marques-Ibanez (2011) show that banks with weaker core capital positions restricted the loan supply more strongly during the $2007-10$ crisis period.

How can European and Japanese banks raise capital in difficult times? Acharya, Schoenmaker and Steffen (2011) argue that banks could raise capital on the market through deeply discounted rights issues. Current shareholders would have the right to buy the newly issued shares. They would have an incentive to do so because the new shares are under-priced 
(deeply discounted). If they do not have the necessary cash, current shareholders can sell the new shares. Recent examples are UniCredit, which raised $€ 13$ billion in fresh capital through a rights issue in early $2017^{2}$, and Deutsche Bank, which announced a rights issue in March 2017. Another source of capital is retained earnings, which banks can increase by reducing dividends.

\subsection{Cross-border banking}

On cross-border banking, the country picture is slightly different from that on size. Again, the Asian banks show an increase in globalisation, with an uptick in foreign activities of 3 percentage points for Chinese banks and 8 percentage points for Japanese banks (see the bottom panel of Table 3). By contrast, US banks have experienced a reduction in foreign activity, which can be partly explained by the stronger performance of the US economy than the EU economy (the major receiver of international US banking services). This stronger economic performance in the US created more business opportunities at home for the US banks.

For the European banks, the geographic picture is similar to that on size. The UK and Swiss banks show a strong decline in foreign banking ( -4 and -7 percentage points), with the decline concentrated in regional banking. So the UK and Swiss banks reduced their activities in Europe, but not at the global level. For the euro-area banks the picture is almost flat. Table 3 indicates a slight uptick of domestic and European activities (both 1 percentage point) and a similar decline in global business of -2 percentage points. The euro-area banks are thus maintaining a strong geographic footprint with 30 percent of their business in Europe (outside their home country) and 22 percent in the rest of the world.

While the country patterns are balanced (apart from the fact that both the UK and Switzerland are declining), the overall picture is more pronounced. The total foreign share of global banks (all G-SIBs) fell from 44 percent in 2007 to 35 percent in 2015. This decline of 9 percentage points reflects a 20 percent decline in global banking, which is in line with other research findings. Claessens (2017), for example, also reports a 20 percent decline in global banking.

What are the underlying causes of this large decline? To answer this question, we split the 9 percentage points decline (which is a weighted average for the group of banks) into a decline caused by changes in the geographical spread at individual banks and a decline arising from changes in the relative shares of individual banks in the group of banks (the composition effect). Table 5 reports that only 16 percent is due to changes in the geographic spread at individual G-SIBs, which is in line with the moderate effects that we find at the country level. G-SIBs are like large oil tankers - they find it difficult to change course. It only happens after a major event. The largest part of the decline (84 percent) comes thus from changes in the size of individual G-SIBs, which measures their relative contribution to the group.

Table 3 reports the growth of Chinese banks, and to a lesser extent that of Japanese and US banks. These banks are less international than the European banks, which have shrunk since the crisis. As a result, the amount of cross-border activity in percent of total size of all the banks' balance sheets has decreased. So the vast part of the decline of global banking is a result of the rise of the more domestically-oriented Chinese banks and the decline of the more global European banks.

2 See the press release 'UniCredit: rights issue fully subscribed,' UniCredit, 2 March 2017. 
Table 5: Change in cross-border banking of G-SIBs [2007-2015]

\begin{tabular}{ccc}
\hline & Changes (in percentage points) & Share in overall change (in \%) \\
\hline $\begin{array}{c}\text { Changes in geographical } \\
\text { spread }\end{array}$ & $-1.6 \%$ & $16 \%$ \\
\hline Changes in bank size & $-8.3 \%$ & $84 \%$ \\
\hline Combined effect & $1.2 \%$ & \\
\hline Overall change 2007-15 & $-8.7 \%$ & \\
\hline
\end{tabular}

Source: Bruegel (see Table 3). Notes: The overall change in cross-border banking from 2007 to 2015 (bottom row) is split into a part arising from changes in the geographical spread of individual G-SIBs and a part arising from changes in the size of individual G-SIBs which measures their relative share in the total group of G-SIBs (the composition effect). The third row is the combined effect of spread and bank share changes.

\section{Policy implications and conclusions}

We conclude that reports on the death of global banking are greatly exaggerated. The excessive increase in cross-border banking in the run up to the global financial crisis has been reversed. We have returned to the 2006 level of globalisation, and that has remained flat over the last few years. In particular, we find that the regional and global shares of cross-border banking both declined by 20 percent between 2007 and 2015 .

Interestingly, the reduction in cross-border banking is only partly a result of the declining foreign shares of individual banks. A major part (84 percent) of the 20 percent decline in cross-border banking can be explained by the composition effect: changes in the ranking within the G-SIBs champions' league. The large Chinese banks with very limited cross-border banking have risen spectacularly (more than 200 percent from 2007-15), while the global UK and Swiss banks have witnessed a substantial drop of about 40 percent. In response to the crisis, the UK and Swiss authorities have implemented structural reforms with the aim of improving the resilience of their large banks and of reducing the size and foreign reach of these banks (Schoenmaker, 2016).

An important policy measure is the increase in capital at G-SIBs. Overall, we find an almost doubling of the leverage ratio from 3.1 percent in 2007 to 5.9 percent in 2015. This is very welcome. However, we note that the euro area, Japan, Sweden and Switzerland trail behind with leverage ratios between 4 and 5 percent. We recommend that these countries should bring the leverage ratios of their largest banks more into line with international practice.

The euro-area banks are in the twilight zone. These banks have reduced in size (about 20 percent), which was to be expected because of overbanking in Europe (Langfield and Pagano, 2016), but have retained their geographical reach. However, the capitalisation of euro-area banks lags that of their Chinese and US peers. While the European Central Bank has already made progress on the size and consistency of Pillar 2 capital requirements (Schoenmaker and Véron, 2016), we strongly recommend reinforcing the capitalisation of the euro-area banks further. Increasing capital can be done through a combination of retained earnings and rights issues.

A final point for the euro-area banks is the fiscal backstop, which is important for financial stability and geopolitical reasons (Schoenmaker, 2016). The ECB is already responsible for the prudential supervision of the G-SIBs in the euro area. Financial stability requires further strengthening of the euro-area's unfinished banking union to generate the desired incentives for banks and national authorities. Further risk sharing (through the European Stability Mechanism) should go hand-in-hand with additional harmonisation initiatives and the limitation of banks' holdings of individual countries' sovereign bonds (Sapir et al, 2017). A completed banking union would bring the euro-area banks to par with the Chinese and US banks, which have a central system of supervision and crisis management behind them. 


\section{References}

Acharya, V., D. Schoenmaker and S. Steffen (2011) 'How much capital do European banks need? Some estimates, VoxEU, 22 November

Berger, B., P. Hüttl and S. Merler (2016) ‘Total Assets versus Risk Weighted Assets: Does it Matter for MREL?' Policy Contribution 2016/12, Bruegel

Cerutti, E. and S. Claessens (2017) 'The great cross-border bank deleveraging: supply side characteristics and intra-group frictions', Review of Finance, forthcoming

Claessens, S. (2017) 'Global Banking: Recent Developments and Insights from Research', Review of Finance, forthcoming

Claessens, S. and N. van Horen (2014) 'Foreign banks: trends and impact', Journal of Money, Credit and Banking, 46: 295-326

De Haas, R., U. Korniyenko, E. Loukoianova, and A. Pivovarsky (2015) 'Taming the herd? Foreign banks and the Vienna initiative: turning sinners into saints', Journal of Financial Intermediation 24: 325-355

Demir, B., T. Michalski and E. Örs (2016) 'Risk-Based Capital Requirements for Banks and International Trade', CEPR Discussion Paper No. 11565

Duijm, P. and D. Schoenmaker (2017) 'European Banks Straddling Borders: Risky or Rewarding?' Rotterdam School of Management, mimeo

Financial Stability Board (2016) '2016 list of global systemically important banks (G-SIBs)', Basel

Financial Times (2016) 'Basel Bashing', 11 October

Gambacorta, L. and D. Marques-Ibanez (2011) 'The bank lending channel: lessons from the crisis', Economic Policy, 26(66): 135-182

Goodhart, C. (2012) 'The Vickers Report: an assessment', Law and Financial Markets Review 6: 32-38

Liikanen Report (2012) High-level Expert Group on Reforming the Structure of the EU Banking Sector, Final Report, Brussels

Kleymenova, A., A. Rose and T. Wieladek (2016) 'Does Government Intervention Affect Banking Globalization?' Journal of the Japanese and International Economies, 40(C): 43-58

Langfield, S. and M. Pagano (2016) 'Bank bias in Europe: effects on systemic risk and growth', Economic Policy, 31(85): 51-106

Marshall White, F. (1897) 'Mark Twain Amused', New York Journal, 2 June

McCauley, R., P. McGuire and G. von Peter (2012) 'After the global financial crisis: From international to multinational banking?' Journal of Economics and Business, 64(1): 7-23

Rose, A. and T. Wieladek (2014) 'Financial Protectionism? First Evidence', The Journal of Finance, 69(5): 2127-2149

Sapir, A., D. Schoenmaker and N. Véron (2017) 'Making the Best of Brexit in Finance: The EU27 Side', Policy Brief 2017/01, Bruegel

Schoenmaker, D. (2013) Governance of International Banking: The Financial Trilemma, Oxford University Press, New York

Schoenmaker, D. (2016) ‘Resolution of International Banks: Can Smaller Countries Cope?' CEPR Discussion Paper 11600

Schoenmaker, D. and N. Véron (2016) European Banking Supervision: The First Eighteen Months, Blueprint 25, Bruegel

Schoenmaker, D. and W. Wagner (2013) 'Cross-border Banking in Europe and Financial Stability', International Finance, 16, 1-22 